\title{
PERBANDINGAN TEPUNG SORGUM (Sorgum bicolor L. moench) DENGAN TEPUNG UMBI GANYONG (Canna edulis) DAN KONSENTRASI GLISEROL MONOSTEARATE TERHADAP MUTU COOKIES NON GLUTEN FORTIFIKASI
}

\author{
Wisnu Cahyadi, Yudi Garnida, Farida Nurcahyani \\ Program Studi Teknologi Pangan, Fakultas Teknik, Universitas Pasundan, J1. Dr. Setiabudhi No.193, Bandung, 40153, \\ Indonesia \\ E-mail : wisnucahyadi@unpas.ac.id
}

\begin{abstract}
Abstrak
Tujuan penelitian adalah untuk mengetahui bagaimana pengaruh dari tepung sorgum dengan tepung umbi ganyong dan penambahan GMS terhadap mutu cookies yang dihasilkan. Metode penelitian yang dilakukan terdiri dari penelitian pendahuluan dan penelitian utama. Penelitian pendahuluan dilakukan untuk menentukan formulasi dan lama waktu pemanggangan. Penelitian utama dilakukan untuk mengetahui pengaruh perbandingan tepung sorgum dengan tepung umbi ganyong dan penambahan GMS terhadap mutu cookies. Rancangan percobaan yang digunakan adalah Rancangan Acak Kelompok (RAK), faktor pertama yaitu perbandingan tepung sorgum dengan tepung umbi ganyong 60\%:40\%, 65\%:35\% dan 70\%:30\%, sedangkan faktor kedua yaitu konsentrasi GMS 0,5\%; 1\% dan 1,5\%. Respon pada penelitian ini adalah organoleptik meliputi atribut warna, aroma, rasa dan tekstur, respon kimia meliputi kadar air, karbohidrat, protein, lemak, fe, dan yodium, respon mikrobiologi meliputi E.coli dan jumlah total mikroba, respon fisik menggunakan texture analyzer dengan parameter kekerasan dan kemudah patahan. Hasil penelitian menunjukkan bahwa perbandingan tepung sorgum dengan tepung umbi ganyong berpengaruh terhadap respon kimia yaitu kadar air serta respon organoleptik yaitu atribut warna, aroma, tekstur dan rasa. Konsentrasi GMS hanya berpengaruh terhadap respon tekstur, namun tidak berpengaruh terhadap atribut lain yaitu warna, aroma dan rasa serta respon kimia yaitu kadar air. Interaksi antara keduanya tidak berpengaruh terhadap respon kimia dan respon organoleptik yang diamati. Berdasarkan hasil analisis kimia dan uji organoleptik didapatkan perlakuan terpilih yaitu alb1 (perbandingan tepung sorgum dengan tepung umbi ganyong 60\%:40\% dan konsentrasi GMS 0,5\%) yang memiliki kadar air 2,44\%, protein 6,125\%, lemak 9,6013\%, karbohidrat 74,3571\%, jumlah total mikroba 2,20x102 cfu/g, jumlah E.coli 0,0 APM, kadar Fe 42,081 ppm dan kadar yodium sebesar 65,804 ppm serta hasil analisis terhadap kekerasan 2792,15 gForce dan kemudahpatahan 19,00 mm..
\end{abstract}

\begin{abstract}
The purpose of this research was to find out how the effect of sorghum flour with canna flour and the addition of GMS to the quality of cookies produced. The research method consists of preliminary research and primary research. Preliminary research was conducted to select the formulation and length of baking time. The main research was conducted to determine the effect of the ratio of sorghum flour to canna tuber flour and the addition of GMS to the quality of cookies. The experimental design used was Randomized Block Design (RBD), the first factor was the ratio of sorghum flour with canna tuber flour 60\%:40\%, 65\%:35\% and 70\%:30\%, while the second factor was $0.5 \%$ GMS concentration. ; $1 \%$ and $1.5 \%$. The responses in this study were organoleptics including attributes of color, aroma, taste and texture, chemical responses including water, carbohydrate, protein, fat, fe, and iodine content, microbiological responses including E.coli and total microbial number, physical response using texture analyzer with parameters of violence and ease of fracture. The results of the main study showed that the ratio of sorghum flour to canna tuber flour had an effect on the chemical response, namely moisture content and organoleptic response, namely the attributes of color, aroma, texture and taste. GMS concentration only affects the texture response, but does not affect other attributes, namely color, aroma and taste and chemical response, namely water content. The interaction between the two did not affect the chemical response and the observed organoleptic response. Based on the results of chemical analysis and organoleptic test, the selected treatment is a1b1 (ratio of sorghum flour with $60 \%: 40 \%$ canna flour and $0.5 \%$ GMS concentration) which has a water content of $2.44 \%$, protein $6.125 \%$, fat $9.6013 \%$, carbohydrates $74,3571 \%$, total microbes 2,20x102 cfu / g, E.coli 0,0 APM, Fe 42,081 ppm and iodine levels 65,804 ppm and results of analysis on hardness of 2792,15 gForce and ease of 19,00 mm
\end{abstract}

Keywords: cookies, sorghum flour, canna flour, GMS

\section{Pendahuluan}

Masalah kekurangan gizi yang selama ini terjadi pada masyarakat akan diatasi dengan adanya fortifikasi pada produk pangan yang dibuat, yang juga disertai dengan penambahan zat besi. Karena menurut Raharjo (2004), zat besi dapat menginisiasi terjadinya 
peroksidasi lemak dan juga oksidasi protein. Logam $\mathrm{Fe}$ dapat menginduksi terjadinya peroksidasi lemak, terutama pada rantai asal lemak tidak jenuh ganda (PUFA). Lemak mengalami oksidasi ini akan menjalani reaksi lanjutan secara berantai membentuk produk radikal bebas seperti radikal alkil, radikal alkoksil, radikal peroksil, dan hidroperoksida. Peningkatan jumlah radikal ini akan mengakibatkan terjadinya dekomposisi asam lemak tidak jenuh menjadi lipid peroksida yang sangat tidak stabil. Oksidasi protein adalah modifikasi kovalen dari protein yang diinduksi baik secara langsung oleh spesies oksigen reaktif atau tidak langsung melalui reaksi dengan produk sekunder dari stres oksidatif (Shacter, 2000, didalam Astuti, 2014).

Dibalik keragaman cara untuk meningkatkan nilai gizi suatu produk pangan yang salah satunya adalah dengan cara fortifikasi, di Indonesia sendiri produk olahan pangan akhir-akhir ini mengalami perkembangan yang sangat pesat. Hal ini disebabkan oleh perubahan gaya hidup masyarakat yang ingin serba cepat sehingga produksi makanan pun mencari produk yang siap saji namun dapat mencukupi kebutuhan gizi setiap hari. Produk olahan yang banyak digemari masyarakat di Indonesia antara lain roti, biskuit, mie, dan termasuk cookies.

Cookies merupakan alternatif makanan selingan yang cukup dikenal dan digemari oleh masyarakat. Cookies dikategorikan sebagai makanan ringan karena dapat dikonsumsi setiap waktu (Departemen Perindustrian RI, 1990). Cookies merupakan salah satu jenis biskuit yang dibuat dari adonan lunak, renyah dan bila dipatahkan penampangnya tampak bertekstur kurang padat (BSN, 2011).

Dalam pengolahan cookies hal yang harus diperhatikan adalah kerenyahannya. Bahan baku yang digunakan dalam pembuatan cookies dapat mempengaruhi kualitas akhir cookies, terutama tepung yang digunakan. Tepung yang biasa digunakan untuk membuat cookies adalah tepung terigu. Terigu memiliki komponen terbesar pati dan memiliki protein gliadin dan glutenin yang dapat membentuk gluten. Gluten yang terbentuk berfungsi untuk membentuk karakteristik cookies yang diinginkan.

Terigu memiliki kelemahan, diantaranya kandungan gluten pada terigu yang ternyata tidak dapat dikonsumsi sebagian orang. Selain itu, terigu juga dibuat dari bahan baku gandum yang diimpor.

Penderita autis tidak bisa mencerna gluten dengan sempurna. Kombinasi asam amino yang ada di dalam gluten tidak dapat dipecah menjadi asam amino tunggal oleh sistem pencernaan anak dengan gangguan autis, tetapi masih dalam bentuk peptida. Peptida yang tidak tercerna tersebut dapat diserap oleh usus halus yang selanjutnya masuk ke dalam peredaran darah dan diteruskan ke reseptor opioid otak. Peningkatan aktivitas opioid akan menyebabkan gangguan susunan saraf pusat dan dapat menyebabkan efek kuat pada perilaku, sama halnya dengan heroin atau morfin. Zat ini menyebabkan berbagai masalah, seperti mengantuk, tidak memiliki perhatian atau bengong, dan memiliki perilaku yang agresif (Sari, 2009).

Masalah impor gandum yang terus meningkat dan masyarakat yang tidak dapat mengkonsumsi gluten atau produk olahan tepung terigu dapat ditanggulangi secara mendasar dan berkesinambungan melalui pemanfaatan sumber pangan lokal. Komoditas tanaman pangan yang dapat tumbuh dengan baik pada iklim tropis dan menghasilkan tepung sebagai pengganti tepung terigu diantaranya adalah sorgum dan umbi ganyong. Kedua jenis tepung ini berasal dari varietas tanaman yang banyak terdapat di Indonesia, yang penggunaannya belum dapat dimanfaatkan secara maksimal.

Menurut Suarni (2004), sorgum mempunyai kandungan pati sekitar $80,42 \%$, lemak $3,65 \%$, protein $10,11 \%$, abu 2,24\%, serat kasar 2,74\%. Sorgum merupakan bahan pangan alternatif yang menempati urutan kelima setelah beras, jagung, dan gandum bagi penduduk di Benua Asia dan Afrika, dan menempati urutan serealia kelima terpenting sebagai bahan pangan manusia yang dikonsumsi oleh lebih dari 500 juta orang di lebih dari 30 negara.

Bahan pangan lokal selain sorgum yang dapat dimanfaatkan sebagai bahan pengganti tepung terigu adalah umbi ganyong. Indonesia merupakan negara yang sangat kaya dengan keragaman plasma nutfah termasuk umbi-umbian. Lebih dari 30 jenis umbiumbian yang biasa ditanam dan dikonsumsi rakyat Indonesia diantaranya adalah umbi ganyong. Pengembangan tepung ganyong memiliki nilai strategis sebagai pangan alternatif dalam rangka diversifikasi pangan berbasis sumber daya lokal. Hal ini nantinya dapat memperkuat ketahanan pangan di Indonesia dan meningkatkan pertumbuhan ekonomi di Indonesia.

Bahan tambahan pangan yang dapat menunjang kualitas dari produk cookies yang akan dihasilkan adalah Gliserol Monostearat (GMS). Penambahan GMS pada pembuatan cookies juga dapat memperbaiki kualitas karena meningkatkan kerenyahan dan meningkatkan kelembutan cookies (Sindhuja et al, 2005). Gliserol Monostearat (GMS) adalah surfaktan non-ionik yang banyak digunakan oleh industri stabilizer dan emulsifier.

Oleh karena itu, dilakukan penelitian untuk mengetahui pengaruh perbandingan tepung sorgum dengan tepung umbi ganyong dan konsentrasi gliserol monostearate terhadap mutu cookies non gluten fortifikasi.

\section{Bahan dan Metode Penelitian}

Bahan-bahan yang digunakan dalam pembuatan cookies ini adalah tepung sorgum, tepung umbi ganyong, kuning telur, margarine, baking powder, vanili, susu bubuk, gula halus, GMS, Fe2SO4 dan KIO3. Bahan-bahan yang digunakan untuk analisis kimia adalah kalium iodida, reagen Luff Schoorl, 
$\mathrm{Na} 2 \mathrm{~S} 2 \mathrm{O} 3$, pelarut heksan, $\mathrm{KMnO} 4, \mathrm{HCl}$ pekat, $\mathrm{H} 2 \mathrm{SO} 4$, amilum, $\mathrm{H} 2 \mathrm{SO} 4$ encer, $\mathrm{NaOH}$, dan aquadest.

Alat-alat yang digunakan dalam penelitian adalah oven, timbangan digital, mixer, sendok, loyang, cetakan semprit, spatula dan baskom. Peralatan yang digunakan untuk analisis kimia yaitu desikator, kaca arloji, oven, timbangan digital, penjepit, kuvet, corong pisah, gelas ukur, kolorimeter, spektrofotometer UV-Vis, tabung reaksi, rak tabung, penangas air, pipet tetes dan volumetri, beaker glass, kertas saring, labu ukur 100 mL,erlenmeyer, gelas ukur, gelas kimia, pemanas, lumpang dan mortil, desikator.

Terdapat dua tahapan penelitian yaitu pendahuluan dan utama. Tujuan dari penelitian pendahuluan ini adalah untuk menentukan formulasi serta waktu pemanggangan terpilih yang akan digunakan pada penelitian utama secara orgnoleptik terhadap atribut warna, aroma, rasa dan kerenyahan dengan menggunakan uji hedonik. Beberapa variasi formulasi dapat dilihat pada Tabel 1, sedangkan variasi waktu pemanggangan yang akan digunakan adalah 10, 13 dan 16 menit.

Tabel 1. Formulasi Cookies Penelitian Pendahuluan

\begin{tabular}{|c|c|c|}
\hline \multirow{2}{*}{ Bahan } & \multicolumn{2}{|c|}{ Formulasi (\%) } \\
\cline { 2 - 3 } & I & II \\
\hline Tepung & 40 & 36,75 \\
\hline Vanili & 0,8 & 0,6 \\
\hline Gula Halus & 15 & 22,05 \\
\hline Margarine & 24 & 23,4 \\
\hline Susu Bubuk & 8,63 & 5,3 \\
\hline Kuning Telur & 10 & 10,68 \\
\hline Baking Powder & 0,5 & 0,15 \\
\hline $\mathrm{KIO}_{3}$ & 0,05 & 0,05 \\
\hline $\mathrm{Fe}_{3} \mathrm{SO}_{4}$ & 0,025 & 0,025 \\
\hline $\mathrm{GMS}$ & 1 & 1 \\
\hline
\end{tabular}

Penelitian utama yang dilakukan yaitu penentuan perbandingan antara tepung sorgum dengan tepung ganyong serta konsentrasi GMS yang akan ditambahkan. Rancangan percobaan yang digunakan dalam penelitian ini adalah pola faktorial $3 \times 3$ dalam Rancangan Acak Kelompok (RAK) dengan 3 kali ulangan sehingga diperoleh sebanyak 27 kombinasi percobaan. Rancangan perlakuan pada pembuatan cookies terdiri dari 2 faktor, yaitu perbandingan tepung sorgum dengan tepung ganyong (A) dan konsentrasi GMS (B). Faktor A terdiri dari 3 taraf, yaitu :

$\mathrm{a} 1=60 \%: 40 \%$

$\mathrm{a} 2=65 \%: 35 \%$

$\mathrm{a} 3=70 \%: 30 \%$

sedangkan faktor B terdiri dari 3 taraf, yaitu :

$\mathrm{b} 1=0,5 \%$

$\mathrm{b} 2=1 \%$

$\mathrm{b} 3=1,5 \%$

Respon yang akan diuji diantaranya kadar air dengan metode Gravimetri (AOAC, 2010), dan analisis pada sampel terpilih yaitu kadar karbohidrat dengan metode Luff Schoorl, kadar lemak dengan metode sokhlet (AOAC, 2005), kadar protein dengan metode
Kjedahl (AOAC, 2005), kadar zat besi menggunakan AAS, kadar iodida menggunakan spektrofotometer UV. uji hedonik terhadap sifat sensoris dari bahan yang diuji, yaitu warna, aroma, rasa, dan tekstur. Selanjutnya, pada produk terpilih dilakukan pengujian tekstur fisik dengan texture analyzer (kekerasan dan kemudahpatahan), E.coli, serta total plate count (TPC).

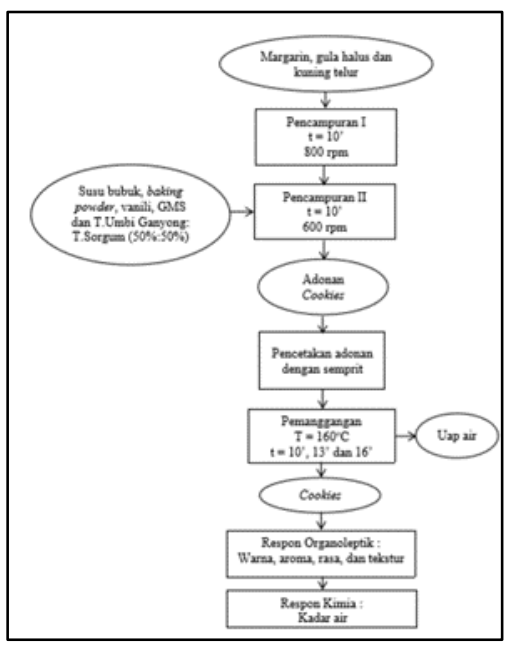

Gambar 1. Diagram Alir Peneitian Pendahuluan

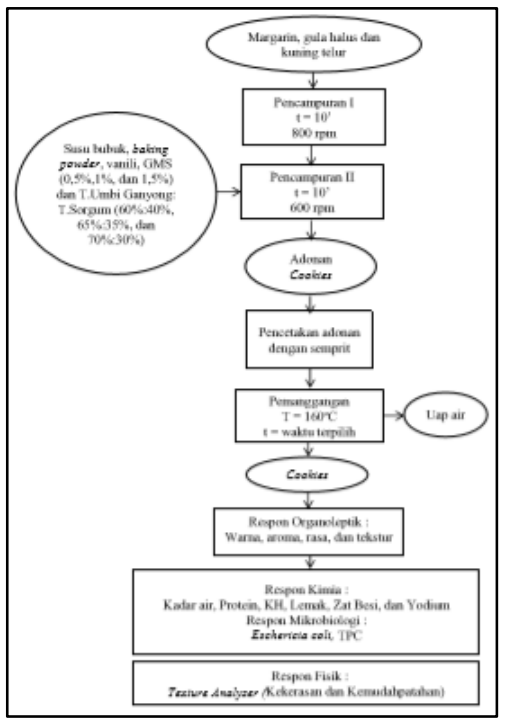

Gambar 2. Diagram Alir Penelitian Utama

\section{Hasil dan Pembahasan}

\section{Penelitian Pendahuluan}

Nilai rata-rata analisis penentuan perlakuan terpilih penelitian pendahuluan dapat dilihat pada Tabel 2 .

Tabel 2. Hasil Penelitian Pendahuluan

\begin{tabular}{|c|c|c|c|c|c|}
\hline \multirow{2}{*}{ Perlakuan } & \multicolumn{5}{|c|}{ Organoleptik } \\
\cline { 2 - 6 } & \multicolumn{5}{|c|}{ Kimia } \\
\cline { 2 - 6 } & Warna & Aroma & Rasa & Tekstur & Air (\%) \\
\hline $\mathrm{a}_{1} \mathrm{~b}_{1}$ & 4,10 & 4,77 & 3,93 & 4,17 & 2,94 \\
\hline $\mathrm{a}_{1} \mathrm{~b}_{2}$ & 4,03 & 4,00 & 3,80 & 3,77 & 2 \\
\hline $\mathrm{a}_{1} \mathrm{~b}_{3}$ & 3,57 & 3,80 & 3,53 & 3,40 & 1,89 \\
\hline $\mathrm{a}_{2} \mathrm{~b}_{1}$ & 4,43 & 4,40 & 4,73 & 4,47 & 2,86 \\
\hline $\mathrm{a}_{2} \mathrm{~b}_{2}$ & 3,80 & 4,23 & 4,27 & 4,07 & 1,98 \\
\hline $\mathrm{a}_{2} \mathrm{~b}_{3}$ & 3,20 & 3,70 & 4,22 & 3,80 & 1,85 \\
\hline
\end{tabular}


Keterangan :

a1b1 = Formulasi 1, dengan waktu pemanggangan 10 menit a1b2 = Formulasi 1, dengan waktu pemanggangan 13 menit a1b3 = Formulasi 1, dengan waktu pemanggangan 16 menit $\mathrm{a} 2 \mathrm{~b} 1=$ Formulasi 2 , dengan waktu pemanggangan 10 menit $\mathrm{a} 2 \mathrm{~b} 2$ = Formulasi 2, dengan waktu pemanggangan 13 menit a2b3 = Formulasi 2, dengan waktu pemanggangan 16 menit

\section{Kadar Air}

Berdasarkan hasil analisis kadar air menggunakan metode gravimetri, semua produk cookies yang dihasilkan sudah memenuhi standar SNI cookies karena masih berada dibawah angka maksimal yaitu 5\%. Hasil kadar air cookies dengan waktu pemanggangan 16 menit lebih rendah dibandingkan dengan waktu pemanggangan 10 menit dan 13 menit. Hal ini terjadi karena panas yang disalurkan melalui alat pemanggangan akan menguapkan air yang terdapat dalam bahan yang dipanggang (Ketaren, 2005, dalam Sitoresmi, 2012). Sehingga semakin lama produk berinteraksi dengan panas maka kadar airnya akan semakin menguap dan berkurang. Namun, untuk hasil kadar air yang tinggi dapat disebabkan oleh beberapa kemungkinan seperti penyimpanan yang kurang baik sehingga ada pengaruh dari tempat penyimpanan yang tidak terkontrol, dan juga beberapa perlakuan yang tidak sesuai selama proses pengolahan

\section{Uji Organoleptik}

a. Warna

Terhadap respon warna diketahui bahwa waktu pemanggangan 10 menit lebih disukai karena memiliki warna mendekati khas cookies dibandingkan perlakuan lain. Lama pemanggangan 16 menit tidak disukai karena warnanya yang terlalu gelap cenderung gosong. Dengan adanya protein dalam cookies juga dapat menyebabkan reaksi maillard. Menurut Winarno (2004), reaksi maillard terjadi karena adanya reaksi antara gugus karbohidrat (gula pereduksi) dengan gugus amino (protein) dalam suhu tinggi.

Komposisi ganyong yang ditambahkan juga mempengaruhi tingkat kesukaan panelis, karena semakin banyak jumlah tepung yang ditambahkan akan menjadikan warna produk menjadi kurang menarik. Menurut Natalianingsih (2005), ganyong mengandung karbohidrat yang tinggi yaitu sebesar 85,20 g maka pada saat baking karbohidrat mengalami proses browning atau pencoklatan karena karbohidrat terutama glukosa dan fruktosa akan kehilangan air menghasilkan glukosan dan fruktosan dengan adanya perubahan warna coklat.

\section{b. Aroma}

Selama proses pemanggangan cookies terjadi perubahan fisik dan kimiawi yang kompleks, yaitu adonan berubah menjadi ringan, berpori dan beraroma. Pembentukan flavor bahan pangan umumnya terjadi akibat adanya proses pemanasan. Dengan adanya proses pemanasan yang lebih lama maka flavor yang terbentuk juga akan hilang karena komponen pembentukan flavor adalah aromatik mudah menguap (volatile component) (Ridal, 2003). Tingkat kesukaan panelis terus menurun seiring dengan bertambahnya lama waktu pemanggangan, hal ini terjadi karena aroma khas cookies sudah mulai menghilang.

Aroma cookies yang lebih disukai oleh panelis pada Tabel 2 adalah produk yang dihasilkan dengan komposisi bahan pada formulasi I, hal ini berkaitan dengan penambahan vanili dan susu bubuk yang lebih banyak dibandingkan dengan formulasi II. Dimana vanili dan susu bubuk sendiri berperan dalam meningkatkan aroma pada cookies sehingga dapat menutupi aroma dari tepung sorgum dan tepung umbi ganyong yang kuat dan kurang disukai oleh panelis.

\section{c. Rasa}

Berdasarkan hasil pengujian atribut rasa pada Tabel 2, perlakuan waktu pemanggangan 10 menit lebih disukai panelis karena lama pemanggangan 13 menit dan 16 menit menimbulkan rasa yang sedikit pahit akibat cookies yang terlalu matang karena adanya reaksi karamelisasi yang ditimbulkan oleh gula yang ditambahkan dalam adonan.

Winarno (1999) menyebutkan bahwa karamelisasi diawali dengan proses pemecahan sukrosa menjadi glukosa dan fruktosan (fruktosa yang kekurangan satu molekul air). Dengan adanya suhu tinggi akan menyebabkan molekul air dari setiap molekul gula keluar, sehingga terbentuk glukosa yang dilanjutkan dengan dehidrasi polimerisasi. Kemudian apabila gula dipanaskan di atas titik leburnya sendiri, maka warnanya akan berubah menjadi coklat yang disertai dengan perubahan cita rasa.

Selain itu penambahan tepung ganyong dan tepung sorgum dengan jumlah yang lebih banyak akan mempengaruhi rasa yang disebabkan oleh adanya senyawa fenol dan tanin sehingga menurunkan tingkat kesukaan pada cookies yang dihasilkan karena menimbulkan rasa sedikit getir dan pahit.

\section{d.Tekstur}

Dalam atribut tekstur, produk cookies yang dihasilkan yang paling disukai adalah cookies dengan formulasi II dan waktu pemanggangan 10 menit. Hal yang paling berpengaruh adalah perbedaan banyak margarine yang ditambahkan. Semakin rendah margarine yang ditambahkan, maka cookies akan semakin keras. Hal ini disebabkan oleh jumlah lemak yang terabsorpsi sedikit dan akan menghalangi struktur serat yang kuat.

Menurut Sultan (1990) didalam Wulandari (2018), margarine dapat digunakan sebagai pengempuk dan membantu pengembangan fisik cookies. Oleh karena itu, semakin tinggi penambahan margarine, maka tekstur produk akan semakin lembut. Selain itu, dengan waktu pemanggangan 10 menit juga sudah sangat cukup untuk membuat produk menjadi matang dan memiliki tekstur yang sesuai dan renyah. 


\section{Penentuan Perlakuan Terpilih}

Berdasarkan analisis yang telah dilakukan terhadap kadar air dan pengujian organoleptik dengan atribut warna, aroma, rasa dan tekstur telah didapatkan hasil akhir dengan metode pemberian skor terhadap tiap respon yang dapat dilihat pada Tabel 3.

Tabel 3. Hasil Skoring Penentuan Perlakuan Terpilih

\begin{tabular}{|c|c|c|c|c|c|c|}
\hline \multirow{3}{*}{ Perlakuan } & \multicolumn{7}{|c|}{ Respon } & Kimia & \multirow{2}{*}{ Total } \\
\cline { 2 - 6 } & \multicolumn{5}{|c|}{ Organoleptik } & Aroma \\
\cline { 2 - 6 } & Warna & Rasa & Tekstur & Air & \\
\hline $\mathrm{a}_{1} \mathrm{~b}_{1}$ & 3 & 4 & 2 & 3 & 1 & 13 \\
\hline $\mathrm{a}_{1} \mathrm{~b}_{2}$ & 3 & 2 & 1 & 2 & 4 & 12 \\
\hline $\mathrm{a}_{1} \mathrm{~b}_{3}$ & 2 & 1 & 1 & 1 & 4 & 9 \\
\hline $\mathrm{a}_{2} \mathrm{~b}_{1}$ & 4 & 3 & 4 & 4 & 1 & 16 \\
\hline $\mathrm{a}_{2} \mathrm{~b}_{2}$ & 2 & 2 & 3 & 3 & 4 & 14 \\
\hline $\mathrm{a}_{2} \mathrm{~b}_{3}$ & 1 & 1 & 2 & 2 & 4 & 10 \\
\hline
\end{tabular}

Maka berdasarkan data di atas dapat disimpulkan bahwa produk terpilih yang akan digunakan pada penelitian utama adalah pelakuan a2b1 yaitu produk dengan formulasi II $(36,75 \%$ tepung sorgum dan tepung umbi ganyong, $0,6 \%$ vanili, $22,05 \%$ gula halus, $23,4 \%$ margarine, 5,3\% susu bubuk, $10,68 \%$ kuning telur, $0,15 \%$ baking powder, $0,05 \% \mathrm{KIO}, 0,025 \% \mathrm{FeSO} 4$, dan $1 \%$ GMS) serta waktu pemanggangan selama 10 menit.

\section{Penelitian Utama}

Penelitian utama yang dilakukan bertujuan untuk mendapatkan perbandingan tepung sorgum dengan tepung umbi ganyong yang sesuai dengan mutu cookies. Perbandingan tepung sorgum dan tepung umbi ganyong yang digunakan pada penelitian ini yaitu 60\%:40\%, 65\%:35\% dan 70\%:30\%. Serta penambahan GMS (Gliserol Monostearate) dengan perbandingan konsentrasi $0,5 \% ; 1 \%$ dan $1,5 \%$.

\section{Kadar Air}

Kadar air adalah persentase kandungan air suatu bahan yang dapat dinyatakan berdasarkan berat basah (wet basis) atau berat kering (dry basis). Pengaruh kadar air sangat penting dalam pembentukan daya awet dari bahan pangan, karena air dapat mempengaruhi sifatsifat fisik atau adanya perubahanperubahan kimia (Buckle et.al., 1987).

Berdasarkan hasil Analisis Variansi (ANAVA) terhadap kadar air cookies menunjukkan bahwa perbandingan tepung umbi ganyong dengan tepung sorgum berpengaruh terhadap kadar air cookies sehingga dilakukan uji lanjut Duncan. Sedangkan konsentrasi GMS dan interaksi antara perbandingan tepung sorgum serta umbi ganyong dengan konsentrasi GMS tidak berpengaruh terhadap kadar air cookies yang dihasilkan.

Menurut Basuki (2013), semakin meningkat penambahan GMS akan menyebabkan peningkatan kadar air pada roti tawar. Purnomo (1994) didalam Basuki (2013), menyatakan bahwa peningkatan daya serap air oleh GMS disebabkan adanya kemampuan pengikatan air oleh gugus polar (hidrofilik) yang dimilikinya. Namun, pada penelitian ini penambahan
GMS tidak berbeda nyata terhadap kadar air cookies yang mungkin disebabkan adanya perbedaan konsentrasi yang hanya sedikit yaitu sebesar $0,5 \%$ dari tiap taraf. Pengaruh perbandingan tepung sorgum dan tepung umbi ganyong terhadap kadar air cookies dapat dilihat pada Tabel 4 .

Tabel 4. Pengaruh Perbandingan Tepung Sorgum dan Tepung Umbi Ganyong Terhadap Kadar Air Cookies $(\%)$

\begin{tabular}{|c|c|}
\hline Perbandingan Tepung Sorgum dan Ganyong & Kadar Air \\
\hline $60 \%: 40 \%$ & $2,95(\mathrm{c})$ \\
\hline $65 \%: 35 \%$ & $2,91(\mathrm{bc})$ \\
\hline $70 \%: 30 \%$ & $2,82(\mathrm{a})$ \\
\hline
\end{tabular}

Keterangan : nilai rata-rata yang ditandai dengan huruf yang berbeda menunjukkan perbedaan pada taraf 5\% uji Duncan.

Hasil penelitian menunjukkan bahwa semakin banyak perbandingan tepung sorgum terhadap tepung umbi ganyong, maka kadar air pada cookies akan menurun. Pengurangan kadar air disebabkan semakin bertambahnya kandungan amilopektin pada adonan seiring dengan penambahan tepung sorgum. Menurut Suprijadi (2012), menyatakan bahwa tepung sorgum mengandung amilosa sebesar $22,73 \%$ dan amilopektin sebesar $53,97 \%$.

Menurut Rodisi (2006), kandungan amilopektin yang tinggi dapat menyebabkan pati sulit untuk mengalami proses gelatinasi sehingga membutuhkan waktu yang lebih lama untuk mencapai suhu gelatinasi. Hal tersebut berdampak pula pada waktu yang dibutuhkan dalam pemanasan (pemasakan) sehingga berlangsung lebih lama pula, sehingga berdampak pada penguapan air yang besar pula. Rendahnya kadar air pada bahan makan akan membuat produk mudah dipatahkan.

Menurut Standar Nasional Indonesia (SNI), syarat mutu kadar air untuk cookies adalah maksimal sebesar $5 \%$. Berdasarkan hasil penelitian, didapat bahwa semua cookies telah memenuhi Standar Nasional Indonesia. Dimana perlakuan perbandingan tepung sorgum dengan tepung umbi ganyong memiliki nilai rata-rata berturutturut $2,95 \% ; 2,91 \%$ dan $2,82 \%$.

\section{Respon Organoleptik}

a.. Warna

Penentuan mutu bahan makanan pada umumnya sangat bergantung pada beberapa faktor, diantaranya cita rasa, warna, tekstur, nilai gizi dan sifat mikrobiologis. Faktor warna secara visual tampil terlebih dahulu dan kadang sangat menentukan. Suatu bahan yang dinilai bergizi, enak, dan teksturnya sangat baik tidak akan dimakan apabila memiliki warna yang tidak sedap dipandang, sehingga warna dapat digunakan untuk menentukan mutu (Winarno, 2004).

Berdasarkan hasil Analisis Variansi (ANAVA) terhadap warna cookies menunjukkan bahwa perbandingan tepung sorgum dengan tepung umbi ganyong berpengaruh terhadap warna cookies, namun konsentrasi GMS dan interaksi antara perbandingan 
tepung sorgum dengan tepung umbi ganyong serta konsentrasi GMS tidak berpengaruh terhadap respon organoleptik dalam atribut warna. GMS memiliki sifat jernih tidak berwarna sehingga tidak akan mempengaruhi warna cookies yang dihasilkan. Pengaruh perbandingan tepung sorgum dengan tepung umbi ganyong terhadap warna cookies dapat dilihat pada Tabel 5.

Tabel 5. Pengaruh Perbandingan Tepung Sorgum dan Tepung Umbi Ganyong Terhadap Warna Cookies

\begin{tabular}{|c|c|}
\hline Perbandingan Tepung Sorgum dan Ganyong & Rata-Rata \\
\hline $60 \%: 40 \%$ & $4,07(\mathrm{c})$ \\
\hline $65 \%: 35 \%$ & $4,06(\mathrm{bc})$ \\
\hline $70 \%: 30 \%$ & $3,9(\mathrm{a})$ \\
\hline
\end{tabular}

Keterangan : nilai rata-rata yang ditandai dengan huruf yang berbeda menunjukkan perbedaan pada taraf 5\% uji Duncan.

Hasil penelitian menunjukkan semakin banyak perbandingan tepung sorgum, warna cookies yang dihasilkan akan semakin tidak disukai oleh panelis karena dapat menghasilkan warna coklat cenderung gelap yang terjadi akibat adanya reaksi maillard, yaitu suatu reaksi antara gugus karbohidrat (gula pereduksi) dengan gugus amino (protein) dalam suhu tinggi.yang menyebabkan warna menjadi gelap (Winarno, 2004).

Warna merupakan salah satu faktor yang menentukan mutu bahan pangan sebelum faktor-faktor lain dipertimbangkan secara visual. Suatu bahan pangan yang bergizi dan tekstur yang baik akan kurang baik jika mempunyai warna yang menyimpang dari warna yang seharusnya. Suatu bahan makanan dinilai bergizi dan enak rasanya namun tidak dimakan apabila memiliki warna yang tidak sedap dipandang atau memberi kesan menyimpang dari warna yang seharusnya. Faktor faktor yang menyebabkan suatu bahan makanan berwarna adalah pigmen alami yang terdapat dalam bahan pangan tersebut (Winarno, 2004).

\section{b. Aroma}

Aroma lebih banyak berhubungan dengan panca indra pembau. Aroma baru dapat dikenali apabila berbentuk uap. Aroma yang diterima oleh hidung dan otak merupakan campuran empat bau utama yaitu harum, asam, tengik, dan hangus. Aroma merupakan faktor yang sangat penting untuk menentukan tingkat penerimaan konsumen terhadap suatu produk, sebab sebelum dimakan biasanya konsumen terlebih dahulu mencium aroma dari produk tersebut untuk menilai layak tidaknya produk tersebut dimakan. Aroma yang enak dapat menarik perhatian, konsumen lebih cenderung menyukai makanan dari aroma (Winarno, 2004).

Berdasarkan hasil Analisis Variansi (ANAVA) terhadap aroma cookies menunjukkan bahwa perbandingan tepung sorgum dengan tepung umbi ganyong berpengaruh terhadap aroma cookies, namun konsentrasi GMS dan interaksi antara perbandingan tepung sorgum dengan tepung umbi ganyong serta konsentrasi GMS tidak berpengaruh terhadap respon organoleptik dalam atribut aroma.

Salah satu sifat dari GMS adalah tidak memiliki aroma yang kuat, sehingga tidak akan mempengaruhi aroma dari cookies yang dihasilkan. Hal ini sesuai dengan pendapat Siregar, dkk (2010) didalam Winarti, dkk (2017) yang menjelaskan bahwa penambahan gliserol monostearat tidak mempengaruhi warna, aroma, dan rasa. Pengaruh perbandingan tepung sorgum dengan tepung umbi ganyong terhadap aroma cookies dapat dilihat pada Tabel 6 .

Tabel 6. Pengaruh Perbandingan Tepung Sorgum dan Tepung Umbi Ganyong Terhadap Aroma Cookies

\begin{tabular}{|c|c|}
\hline Perbandingan Tepung Sorgum dan Ganyong & Rata-Rata \\
\hline $60 \%: 40 \%$ & $4,23(\mathrm{~b})$ \\
\hline $65 \%: 35 \%$ & $4,10(\mathrm{ab})$ \\
\hline $70 \%: 30 \%$ & $4,01(\mathrm{a})$ \\
\hline
\end{tabular}

Keterangan : nilai rata-rata yang ditandai dengan huruf yang berbeda menunjukkan perbedaan pada taraf 5\% uji Duncan.

Hasil pengujian terhadap respon organoleptik atribut aroma menunjukkan bahwa semakin banyak penambahan tepung sorgum akan mengurangi nilai kesukaan panelis terhadap cookies yang dihasilkan karena jumlah amilosa yang terkandung dalam bahan juga meningkat. Menurut Haryadi (2006) didalam Tarmizi (2015), aroma dipengaruhi oleh adanya kandungan amilosa yang terdapat didalam adonan. Bahan yang mengandung amilosa sedang mempunyai nilai aroma yang lebih baik daripada bahan yang mengandung amilosa tinggi, hal ini terjadi karena kadar amilosa sedang memiliki konsistensi gel yang lunak, memiliki afinitas terhadap senyawa-senyawa aroma (volatile) yang lebih rendah daripada bahan beramilosa tinggi.

Namun uji organoleptik pada atribut aroma memiliki hasil yang fluktuatif. Hal ini kemungkinan diakibatkan adanya kesalahan psikologis dari panelis yaitu kesalahan tendensi sentral. Karakteristik kesalahan tendensi sentral ini adalah panelis memberikan nilai tengah pada skala nilai yang ada dan ragu-ragu dalam memberikan nilai tertinggi. Efek dari kesalahan ini adalah panelis menganggap semua sampel yang diuji hampir sama (Kartika dkk., 1987).

c. Rasa

Rasa dalam bahan pangan sangat penting dalam menentukan daya terima konsumen. Selain itu, rasa juga merupakan salah satu faktor yang sangat berpengaruh dalam menentukan mutu. Biasanya rasa sangat diperhatikan oleh konsumen setelah warna. Rasa yang ditimbulkan oleh produk pangan dapat berasal dari bahan itu sendiri juga berasal dari zat-zat yang ditambahkan dari luar saat proses berlangsung, sehingga dapat menimbulkan rasa yang tajam atau setidaknya jadi berkurang (deMan, 1997 didalam Mayasari, 2015).

Berdasarkan hasil Analisis Variansi (ANAVA) terhadap rasa cookies menunjukkan bahwa perbandingan tepung sorgum dengan tepung umbi ganyong berpengaruh terhadap rasa cookies, namun 
konsentrasi GMS dan interaksi antara perbandingan tepung sorgum dengan tepung umbi ganyong serta konsentrasi GMS tidak berpengaruh terhadap respon organoleptik dalam atribut rasa. Pengaruh perbandingan tepung sorgum dengan tepung umbi ganyong terhadap rasa cookies dapat dilihat pada Tabel 7.

Tabel 7. Pengaruh Perbandingan Tepung Sorgum dan Tepung Umbi Ganyong Terhadap Rasa Cookies

\begin{tabular}{|c|c|}
\hline Perbandingan Tepung Sorgum dan Ganyong & Rata-Rata \\
\hline $60 \%: 40 \%$ & $4,49(\mathrm{~b})$ \\
\hline $65 \%: 35 \%$ & $4,21(\mathrm{a})$ \\
\hline $70 \%: 30 \%$ & $4,15(\mathrm{a})$ \\
\hline
\end{tabular}

Keterangan : nilai rata-rata yang ditandai dengan huruf yang berbeda menunjukkan perbedaan pada taraf 5\% uji Duncan.

Hasil pengujian terhadap respon organoleptik atribut rasa menunjukkan bahwa semakin banyak penambahan tepung sorgum akan mengurangi nilai kesukaan panelis terhadap cookies yang dihasilkan. Sorgum mengandung senyawa antinutrisi, terutama tannin yang menyebabkan rasa sepat sehingga tidak disukai konsumen (Kinanti, 2014). Senyawa tersebut juga dapat menyebabkan cookies yang dihasilkan sedikit berasa getir dan pahit, sehingga menurunkan tingkat kesukaan pada rasa cookies yang dihasilkan.

Menurut Siregar, dkk (2010) didalam Winarti, dkk (2017) menjelaskan bahwa penambahan GMS tidak mempengaruhi warna, aroma, dan rasa. Pengaruh antara satu macam rasa dengan rasa yang lain tergantung pada konsentrasinya, bila salah satu komponen mempunyai konsentrasi yang lebih tinggi dari pada komponen yang lain maka komponen tersebut akan dominan.

\section{d. Tekstur}

Tekstur pada biskuit (termasuk cookies) meliputi kekerasan, kemudahan untuk dipatahkan, dan konsistensi pada gigitan pertamanya (Fellows, 2000). Lebih lanjut Fellows menerangkan bahwa tekstur pada makanan sangat ditentukan oleh kadar air, kandungan lemak, dan jumlah serta jenis karbohidrat dan protein yang menyusunnya.

Beberapa sifat cookies yang berhubungan dengan tekstur cookies adalah hardness atau firmness, brittleness, crumbly, dan sticky. Kekerasan (hardness atau firmness) menunjukkan kemampuan cookies untuk mempertahankan bentuk bila dikenai suatu gaya. Kerapuhan (brittleness) yaitu suatu sifat cookies yang mudah pecah bila dikenai suatu gaya, sedangkan crumbly adalah sifat cookies yang mudah hancur menjadi partikel-partikel kecil. Istilah sticky menunjukkan sifat partikel-partikel cookies yang lengket di mulut (Gaines, 1994 dalam Marissa, 2010).

Berdasarkan hasil Analisis Variansi (ANAVA) terhadap tekstur cookies menunjukkan bahwa perbandingan tepung sorgum dengan tepung umbi ganyong (A) dan konsentrasi GMS (B) berpengaruh terhadap tekstur cookies. Namun interaksi antara keduanya tidak berpengaruh nyata terhadap tekstur cookies yang dihasilkan. Pengaruh perbandingan tepung sorgum dengan tepung umbi ganyong (A) dapat dilihat pada Tabel 8.

Tabel 8. Pengaruh Perbandingan Tepung Sorgum dan Tepung Umbi Ganyong Terhadap Tekstur Cookies

\begin{tabular}{|c|c|}
\hline Perbandingan Tepung Sorgum dan Ganyong & Rata-Rata \\
\hline $60 \%: 40 \%$ & $4,18(\mathrm{c})$ \\
\hline $65 \%: 35 \%$ & $4,16(\mathrm{bc})$ \\
\hline $70 \%: 30 \%$ & $3,94(\mathrm{a})$ \\
\hline
\end{tabular}

Keterangan : nilai rata-rata yang ditandai dengan huruf yang berbeda menunjukkan perbedaan pada taraf 5\% uji Duncan.

Hasil pengujian terhadap respon organoleptik atribut tekstur menunjukkan bahwa semakin banyak penambahan tepung sorgum akan mengurangi kesukaan panelis terhadap cookies yang dihasilkan. Hal ini kemungkinan disebabkan oleh jumlah protein pada sorgum yang dapat menyebabkan peningkatan kadar air pada cookies dan mengurangi kekerasan tekstur cookies.

Protein bersifat hidrofilik yaitu mempunyai daya serap air yang tinggi karena adanya gugus karboksil. Namun, kadar protein tinggi yang terkandung dalam tepung sorgum akan meningkatkan daya serap air sehingga tekstur cookies yang dihasilkan akan kokoh.

Tekstur suatu produk berkaitan dengan kadar air dan kadar protein di mana semakin tinggi kadar protein akan semakin menyerap air. Menurut Sultan (1969) dalam Makmoer (2006), daya serap air tergantung dari mutu protein dan jumlah kandungan asam amino polar dalam protein tepung.

Faktor lain yang mempengaruhi tekstur dari cookies yang dihasilkan adalah adanya penambahan GMS dengan beberapa konsentrasi yang berbeda. Hasil penelitian menyatakan bahwa penambahan GMS sebanyak $0,5 \%$ sudah cukup untuk memperbaiki tekstur dari cookies yang dihasilkan dan disukai oleh panelis.

Menurut Sindhuja et al. (2005), penambahan GMS sebanyak $0,5 \%$ dapat meningkatkan daya penerimaan organoleptik pada cookies. Penambahan GMS sebagai emulsifier dapat memperbaiki kualitas karena meningkatkan kerenyahan dan kelembutan cookies, dan juga dapat mengurangi kekakuan adonan selama proses pencampuran. Pengaruh konsentrasi GMS (B) dapat dilihat pada Tabel 9.

Tabel 9. Pengaruh Konsentrasi GMS Terhadap Tekstur Cookies

\begin{tabular}{|c|c|}
\hline Konsentrasi GMS & Rata-Rata \\
\hline $0,5 \%$ & $4,26(\mathrm{c})$ \\
\hline $1 \%$ & $4,07(\mathrm{~b})$ \\
\hline $1,5 \%$ & $3,96(\mathrm{a})$ \\
\hline
\end{tabular}

Keterangan : nilai rata-rata yang ditandai dengan huruf yang berbeda menunjukkan perbedaan pada taraf $5 \%$ uji Duncan.

Uji organoleptik pada atribut tekstur memiliki hasil yang fluktuatif. Hal ini kemungkinan diakibatkan adanya kesalahan psikologis dari panelis yaitu kesalahan tendensi sentral. Karakteristik kesalahan tendensi sentral ini adalah panelis memberikan nilai tengah pada skala nilai yang ada dan ragu-ragu dalam memberikan nilai tertinggi. Efek dari kesalahan ini 
adalah panelis menganggap semua sampel yang diuji hampir sama (Kartika dkk., 1987).

\section{Penentuan Perlakuan Terpilih}

Perlakuan terpilih pada penelitian utama ditentukan dengan analisis statistik metode skoring. Berdasarkan data yang diperoleh dari hasil perhitungan metode skoring maka dapat diambil suatu kesimpulan untuk menentukan sampel terpilih pada penelitian ini. Hasil analisis statistik metode skoring penentuan perlakuan terpilih dapat dilihat pada Tabel 10.

Tabel 10. Hasil Analisis Statistik Metode Skoring Penentuan Perlakuan Terpilih Pada Penelitian Utama

\begin{tabular}{|c|c|c|c|c|c|c|}
\hline \multirow{3}{*}{ Perlakuan } & \multicolumn{6}{|c|}{ Respon } \\
\hline & \multicolumn{4}{|c|}{ Organoleptik } & \multirow{2}{*}{$\begin{array}{l}\text { Kimia } \\
\text { Air }\end{array}$} & \multirow{2}{*}{ Total } \\
\hline & Warna & Aroma & Rasa & Tekstur & & \\
\hline alb1 & 4 & 4 & 3 & 4 & 2 & 17 \\
\hline alb2 & 2 & 4 & 4 & 3 & 1 & 14 \\
\hline alb3 & 2 & 2 & 4 & 2 & 1 & 11 \\
\hline $\mathrm{a} 2 \mathrm{~b} 1$ & 3 & 3 & 2 & 3 & 2 & 13 \\
\hline $\mathrm{a} 2 \mathrm{~b} 2$ & 3 & 2 & 3 & 2 & 2 & 12 \\
\hline $\mathrm{a} 2 \mathrm{~b} 3$ & 2 & 1 & 2 & 2 & 2 & 9 \\
\hline a3b1 & 2 & 1 & 3 & 2 & 4 & 12 \\
\hline $\mathrm{a} 3 \mathrm{~b} 2$ & 1 & 1 & 1 & 1 & 4 & 8 \\
\hline$a 3 b 3$ & 1 & 1 & 1 & 1 & 4 & 8 \\
\hline
\end{tabular}

Berdasarkan penentuan produk terpilih menggunakan metode skoring didapatkan hasil yaitu alb1 dengan perbandingan tepung sorgum dan tepung umbi ganyong 60\%:40\% serta konsentrasi GMS 0,5\%, dengan kadar air 2,92\%. Hasil perlakuan terpilih kemudian dilakukan analisis kimia yaitu kadar karbohidrat (pati), protein, lemak, yodium, Fe, daya serap air, texture analyzer, serta analisis TPC dan E.coli.

Selanjutnya, perlakuan terpilih dilakukan untuk mengetahui pengaruh perbandingan tepung sorgum dengan tepung umbi ganyong dan konsentrasi GMS terhadap respon kimia pada produk. Hasil analisis kimia perlakuan terpilih dapat dilihat pada Tabel 11.

Tabel 11. Hasil Analisis Kimia Perlakuan Terpilih

\begin{tabular}{|c|l|c|c|}
\hline \multirow{2}{*}{ No } & \multicolumn{2}{|c|}{ Pengujian } & \multicolumn{2}{c|}{ Hasil } \\
\cline { 3 - 4 } & & SNI & $\mathrm{a}, \mathrm{b}]$ \\
\hline 1 & Kadar Air & Maks. 5 & $2,92 \%$ \\
\hline 2 & Protein & Min. $5 *$ & $6,125 \%$ \\
\hline 3 & Lemak & Min. 9,5 & $9,6013 \%$ \\
\hline 4 & Pati & Min. 70 & $74,3571 \%$ \\
\hline 5 & TPC (Total Plate Count) & Maks $1 \times 10^{6} \mathrm{cfu} / \mathrm{g}$ & $2,20 \times 10^{2} \mathrm{cfu} / \mathrm{g}$ \\
\hline 6 & E.coli & $<$ & $0,0 \mathrm{APM} / \mathrm{g}$ \\
\hline 7 & Fe & - & $42,041 \mathrm{ppm}$ \\
\hline 8 & Yodium & $30-80 \mathrm{ppm}$ & $65,804 \mathrm{ppm}$ \\
\hline
\end{tabular}

Sumber : SNI 01-2973-1992, *SNI -2973-2011

Hardness (Kekerasan) dan fracturability (kemudahan dipatahkan) dipandang sebagai dua indikator penting dalam menganalisis tekstur makanan terutama dalam produk-produk baked seperti roti dan biskuit (Pratama dkk., 2014).

Kekerasan dapat diukur dengan cara merekam gaya maksimum yang dibutuhkan untuk menekan suatu bahan. Sedangkan kemudahan untuk dipatahkan diukur dengan mengkalkulasi gaya dan jarak yang dibutuhkan untuk menekan bahan sampai terjadinya crack (keretakan). Berdasarkan analisis yang telah dilakukan didapatkan hasil yang dapat dilihat pada Tabel 12 .

Tabel 12. Hasil Pengujian Texture Analyzer Terhadap Cookies

\begin{tabular}{|c|c|c|c|c|}
\hline No & Parameter Analisis & Hasil Analisis & Satuan Hasil & $\begin{array}{c}\text { Metode } \\
\text { Pengujian }\end{array}$ \\
\hline 1 & Kekerasan & 2792,15 & gForce & \multirow{2}{*}{ Kompresi } \\
\hline 2 & Kemudahpatahan & 19,00 & Mm & Kompran \\
\hline
\end{tabular}

Menurut Gaines et al (1992), kadar protein (gluten) dan kemampuan mengikat air berpengaruh pada kekerasan cookies. Makin tinggi kadar protein, makin tinggi kekerasan cookies. Menurut Burt dan Fearn (1983) di dalam Belinda (2009), selama pemanggangan panas berpenetrasi dengan cepat pada bagian bawah dan atas cookies, menyebabkan hilangnya gas pengembang dan air pada bagian tersebut. Penetrasi panas ke bagian dalam cookies lebih lambat, memungkinkan terbentuknya lebih banyak rongga udara. Makin lambat air tertahan, memungkinkan makin banyak pati tergelatinisasi padabagian tengah cookies. Jumlah rongga udara yang terbentuk dan gelatinisasi pati dipengaruhi oleh kecepatan perpindahan panas ke dalam cookies dankecepatan hilangnya air. Makin banyak panas yang masuk, makin banyak rongga udara yang terbentuk dan lebih banyak pati yang tergelatinisasi. Hal ini akan mempengaruhi struktur remah pada cookies.

Berdasarkan hasil penelitian yang telah dilakukan, maka diperoleh kesimpulan sebagai berikut.

1. Hasil penelitian pendahuluan menunjukkan produk cookies terpilih berdasarkan nilai rata-rata analisis statistik metode skoring terhadap respon kimia dan respon organoleptik adalah perlakuan a2b1 dimana formulasi yang terpilih ada formulasi II dengan lama pemanggangan selama 10 menit. Kadar air produk cookies yang dihasilkan yaitu sebesar $2,86 \%$.

2. Perbandingan tepung sorgum dengan tepung umbi ganyong berpengaruh terhadap mutu cookies meliputi respon kimia yaitu kadar air serta respon organoleptik yaitu atribut warna, aroma, rasa dan tekstur.

3. Konsentrasi GMS yang ditambahkan berpengaruh terhadap mutu cookies dengan respon organoleptik yaitu tekstur, namun tidak berpengaruh terhadap respon kimia yaitu kadar air dan respon organoleptik yaitu atribut warna, aroma dan rasa.

4. Interaksi antara perbandingan tepung sorgum dengan tepung umbi ganyong serta penambahan GMS tidak berpengaruh terhadap respon kimia dan respon organoleptik.

\section{Daftar Pustaka.}

1. AOAC. 2010. Official Methods of Analysis of the Association of the Official Analytical Chemist. Washington D. C., USA.

2. AOAC. 2005. Official Methods of Analysis of the Association of the Official Analytical Chemist. Washington D. C., USA.

3. Astuti, Rahayu., dkk. 2014. Komposisi Zat Gizi Tempe Yang Difortifikasi Zat Besi dan Vitamin A 
Pada Tempe Mentah dan Matang. Universitas Muhammadiyah Semarang.

4. Badan Standarisasi Nasional. 2011. Biskuit. 2973 : 2011. Departemen Perindustrian, Jakarta.

5. Basuki, EK., dkk. 2013. Kajian Substitusi Tepung Tapioka dan Penambahan Gliserol Monostearat Pada Pembuatan Roti Tawar. UPN, Jawa Timur.

6. Belinda. 2009. Evaluasi Mutu Cookies Campuran Tepung Kacang Hijau dan Beras Sebagai Pangan Tambahan Bagi Ibu Hamil. Skripsi: Institut Pertanian Bogor, Bogor.

7. Buckle, et.al. 1987. Ilmu Pangan. Universitas Indonesia Press : Jakarta.

8. Departemen Perindustrian RI. 1990. Crackers dan Cookies. Jakarta.

9. Gaspersz, V. 1995. Teknik Analisis dalam Percobaan. Tarsito : Bandung.

10. Kartika dan Bambang. 1987. Pedoman Uji Inderawi Bahan Pangan. Pusat Antar Universitas Pangan dan Gizi. UGM, Yogyakarta.

11. Makmoer, H. 2006. Roti Manis\&Donat. Jakarta: PT.Gramedia Pustaka Utama.

12. Marissa, D. 2010. Formulasi Cookies Jagung dan Pendugaan Umur Simpan Produk dengan Pendekatan Kadar Air Kritis. Skripsi: Fakultas Teknologi Pertanian. Institut Pertanian Bogor, Bogor.

13. Mayasari, Rani. 2015. Kajian Karakteristik Biskuit yang Dipengaruhi Perbandingan Tepung Ubi Jalar Merah dan Tepung Kacang Merah. Skripsi: Universitas Pasundan, Bandung.

14. Natalianingsih. 2005. Analisis Kandungan Gizi dan Sifat Organoleptik Terhadap Cookies Bekatul. Jurnal Fakultas Pertanian. Universitas Bandung Raya, Bandung.

15. Raharjo, B. 2003. Faktor-Faktor yang Berhubungan dengan Anemia pada Pekerja Perempuan di Desa Jetis Kecamatan Sukoharjo Kabupaten Sukoharjo. Thesis Universitas Diponegoro.

16. Ridal, S. 2003. Karakterisasi Sifat Fisiko Kimia Tepung dan Pati Talas dan Kimpul dan Uji Penerimaan a-amilase Terhadap Patinya. Skripsi: Fakultas Teknologi Pertanian, Institut Pertanian Bogor.

17. Rodisi, DJ., dkk. 2006. Pengaruh Substitusi Tepung Ketan dengan Pati Sagu terhadap Kadar Air, Konsistensi dan Sifat Oragonoleptik Dodol Susu. Jurnal Peternakan Indonesia : 11(1): 66-73, 2006.

18. Sari, I. D. 2009. Nutrisi pada Pasien Autis. Cermin Dunia Kedokteran, 89 - 93.

19. Sindhuja A, Sudha ML, Rahim M. 2005. Effect of incorporation of amaranth flour on the quality of cookies. Eur Food Res Technol 221: 597-601.

20. Sitoresmi, M. A. 2012. Pengaruh Lama Pemanggangan dan Ukuran Tebal Tempe Terhadap Komposisi Proksimat Tempe Kedelai. Program Studi S1 Gizi, Fakultas Ilmu Kesehatan, Universitas Muhammadiyah, Surakarta.
21. Soekarto, S. 1985. Penilaian Organoleptik untuk Industri Pangan dan Hasil Pertanian. Bhratara Karya Aksara : Jakarta.

22. Suarni. 2004. Pemanfaatan Tepung Sorgum Untuk Produk Olahan. Jurnal Penelitian dan Pengembangan Pertanian 23 (4):145-151.

23. Suprijadi. 2012. Karakterisasi Sifat Fisik dan Kimia Tepung Sorgum (Sorghum bicolor L) Rendah Tanin. Skripsi: Institut Pertanian Bogor.

24. Tarmizi, M.R. 2015. Pengaruh Perbandingan Konsentrasi Tepung Sorgum Termodifikasi dengan Tepung Terigu dan Suhu Pemanggangan Terhadap Sifat Fisiko Kimia Flakes Ikan Patin. Teknologi Pangan UNPAS, Bandung.

25. Winarno, F. G. 1997. Kimia Pangan dan Gizi. Jakarta: Gramedia Utama

26. Winarti, S. 2010. Makanan fungsional. Yogyakarta.

27. Winarti, S., dkk. 2017. Karakteristik Mi Kering dengan Substitusi Tepung Gembili dan Penambahan Gliserol Monostearat. UPN, Surabaya.

28. Wulandari, Endah. S. 2018. Pengaruh Lama Blanching dan Lama Pemanggangan Terhadap Karakteristik Cookies Ganyong (Canna edulis Ker) Difortifikasi Iodium. Skripsi. Universitas Pasundan. 